\title{
Textbook Evaluation: Teachers' Perspectives on Cutting
}

$$
\text { Edge }
$$

\author{
Ahmad Alshehri \\ Dept. Of Curriculum and Instruction, King Khalid University, Saudi Arabia \\ P.O. Box 157, Abha 61411, Saudi Arabia \\ E-mail: ahmedatif333@hotmail.com
}

\begin{abstract}
Received: May 24, 2016 Accepted: July 12, 2016 Published: July 14, 2016
doi:10.5296/ijele.v4i2.9743 URL: http://dx.doi.org/10.5296/ijele.v4i2.9743
\end{abstract}

\begin{abstract}
This study aimed to evaluate Cutting Edge, a textbook which is currently being taught at Najran University's Preparatory Year Programme. Twelve EFL instructors were asked to share their perspectives about the target textbook, and a forty-item questionnaire, which was developed by Litz (2005), was used for the purposes of the evaluation. The six areas of the textbook that the questionnaire assessed included skills, activities, layout and design, language type, subject and content and practical considerations. The study's findings revealed that the instructors were largely satisfied with a majority of the textbook's features. They were most satisfied with the textbook's layout and design (mean score=3.74), followed by its subject and content (3.65), its skills component (3.63), its activities (3.55) and its language type (3.51). By contrast, the respondents' opinions of the textbook's practical considerations were unclear.

Because the instructors were happy with most aspects of Cutting Edge, it is likely that the textbook will continue to function as a suitable teaching aide during the instruction of English at Najran University's Preparatory Year Programme. However, it is important to note that this evaluation was based on a select pool of instructors' personal opinions. It is therefore highly recommended that learners be given the opportunity to evaluate the textbook, as well.
\end{abstract}

Keywords: textbook evaluation, Cutting Edge, EFL 


\section{Introduction}

The English language is often used as a platform for the instruction of Saudi Arabian undergraduate programmes. For this reason, English instruction has been given a great deal of emphasis during year-long preparatory programmes at institutions like Najran University. These types of programmes ensure that students gain a level of English proficiency that is considered to be acceptable prior to their enrolment in academic programmes. The many factors that are responsible for the effective instruction of English include the course's instructor, the learners in the classroom, the physical environment where the course is held and the materials that aid in the course's instruction. In the current study, a single factor in the instruction of English was evaluated. This factor was Cutting Edge, a textbook which is currently being taught in the general English course (ENG 150) at Najran University's Preparatory Year Programme.

\section{Importance of Textbook Evaluations}

Materials evaluation, as defined by Tomlinson (1998), is 'the systematic appraisal of the value of materials in relation to their objectives and to the objectives of the learners using them' (p. xi). Materials need to be evaluated continuously. For example, pre-use evaluation can be used to determine if a certain set of materials will influence its users and will be suited to a particular context, in-use evaluation can be used to study materials and determine how teachers and learners are dealing with them, and post-use evaluations can examine if a set of materials has proven useful and will achieve the goals of a specific programme (McGrath, 2002; Ellis, 1997).

According to Tomlinson (2003), who considered materials evaluation significant because it provided teachers with insights into the application of language theories,

...it is also because of the realisation that one of the most effective ways of helping teachers to understand and apply theories of language learning - and to achieve personal and professional development - is to provide monitored experience of the process for developing materials.(p.1).

Moreover, Ellis (1998) pointed out that the need for evaluation had become widespread. He declared that the 'Acceptance of the need for evaluation - both to determine to what extent a programme has worked and, more broadly, to facilitate the whole process of curriculum development - is now widespread' (p. 217). Finally, Cunningsworth (1995) identified three major needs for materials evaluation. These included(1) the intention to adopt new course books, (2) the identification of certain strengths and weaknesses and (3) the capacity for materials to aid in the development of teachers and provide insight into a textbook's various components.

\section{Review of Evaluation Frameworks}

This section discusses a variety of criteria and proposals for the evaluation and development of materials that have been built by a range of English instruction experts. According to Littlejohn (1998), 'One of the most obvious sources for guidance in analysing materials is the 
large number of frameworks which exist to aid in the evaluation of a coursebook' (p. 191). In essence, checklists and frameworks are crucial in materials evaluation because they provide clear guidelines for the evaluation of materials. For instance, Byrd (2001) emphasised the importance of evaluation by asserting that the 'systems for evaluation of textbooks generally provide checklists built around numerous aspects of teaching and student-teacher interactions'(p.416). In addition, McGrath (2002) identified the following benefits to using checklists during the evaluation of materials:

1. The evaluation of materials is systematic, ensuring that all elements that are deemed to be important are considered.

2. It is cost effective, permitting a good deal of information to be recorded in a relatively short space of time.

3. The information is recorded in a convenient format, allowing for easy comparison between competing sets of material.

4. It is explicit, and provided the categories are well understood by all involved in the evaluation, offers a common framework. (p. 26).

Although Rubdy (2003) proposed yet another evaluative framework for the assessment of materials, he believed that a pedagogical focus, which is an aspect that more directly aids in the process of teaching and learning, was more important than an external evaluation, which assesses a textbook's size, layout, pricing, binding, typeface, paper quality, etc. As a result, he proposed the follow two stages of analysis for the selection of coursebooks: (1) Assess the content of the textbook in relation to its professed aims and (2) assess its effectiveness in terms of content, the specific needs of the intended learners and the ways in which it serves the teaching and learning process.

Rubdy's framework was primarily focused on the second stage of course textbook analysis. He identified three broad categories for this stage of evaluation, which assessed the validity of the materials in relation to the following: (1) learners' needs, goals and pedagogical requirements (psychological validity), (2) teachers' skills, abilities, theories and beliefs (pedagogical validity) and (3) the thinking that underlies the material author's presentation of content and approach to teaching and learning, respectively (process and content validity).To assess the psychological validity of materials, Rubdy (2003) put forth criteria that considered creativity, cooperation, learner's needs, learner autonomy and self-development. In regards to pedagogical validity, he focused primarily on teachers' levels of guidance, reflection, innovation and exploration. For the assessment of process and content validity, he listed various subcategories that could be taken into account during the selection or evaluation of materials content. These subcategories included layout, content, linkage, grading, balance, practice, methodology, appropriacy, sufficiency, flexibility, authenticity, accessibility, cultural sensitivity and educational validity.

Cunningsworth (1995) is another author who proposed a comprehensive checklist for the selection and evaluation of materials. This checklist was built on the following four guidelines: 


\section{$\triangle$ Macrothink}

1. Coursebooks should correspond to learners' needs. They should match the aims and objectives of the language-learning programme.

2. Coursebooks should reflect the present or future functions of the language that students learn. Instructors should select coursebooks that will help equip students with the ability to use the language they are learning effectively.(p. 15).

In essence, Cunningsworth stressed that teaching and learning materials should be both externally (in terms of layout and physical appearance) and internally (in terms of organisation and language content) evaluated. During internal evaluation, he recommended the selection and detailed evaluation of two or more units from the targeted textbook. Depending on the guidelines mentioned above, Cunningsworth would then divide his checklist into a number of sections that involved the textbook's aims, design, skills topic, methodology, organisation, teachers' guides, language content and a select number of practical considerations that concerned the price and the availability of materials.

In spite of the effectiveness of Cunningsworth's checklist, Hill (1997) criticised its items for being inexplicit and lacking in guidance. Some of them, he claimed, 'are direct Yes/No questions, others are indirect referential questions; in some cases a "yes" answer replicates the vagueness of the question, sending mixed messages that the evaluator needs time to decode' (p.84).

Another evaluative framework, which was proposed by Grant (1987), identified the following three types of evaluation: (1) initial evaluation, (2) detailed evaluation and (3) in-use evaluation. An initial evaluation would allow researchers to briefly look at the materials they wished to evaluate before they decided to proceed with a detailed assessment. At the same time, Grant warned against hasty decisions. To be able to make decisions during the initial evaluation, he recommended prior application of the 'CATALYST' technique. The word CATALYST (Grant, 1987) is formed from the beginning initials of the short questions that are listed below:

C: Communicative?

A: Aims?

T: Teachability?

A: Availability?

L: Level?

Y: Your impression?

S: Student interest?

T: Tried and tested? (p. 119).

\section{Studies Concerning Textbook Evaluation}

The evaluation of textbooks, especially commercial textbooks, has been the primary focus of several existing studies. This section will review a number of these studies and provide insights into their tools, samples, findings and objectives.

The New Interchange textbook series has been evaluated by several researchers in the past. For instance, Riasati and Zare (2010) explored the views of EFL teachers in response to one 
of the most widely used textbooks in Iran. Their aim was to evaluate the textbook and to assess its pedagogical value. They used an evaluative questionnaire to consult 35 teachers and to learn their opinions about specific aspects of the textbook. These included skills, activities, language type, layout and design, subject and content and a select number of practical considerations. The study's results revealed that most of the teachers responded positively to the categories that were mentioned above. However, some instructors complained that the textbook was insufficient in the following areas:

1. The textbook lacked supplementary teaching material.

2. Some parts of the series were beyond the linguistic capacity of the learners.

3. Some of the series' items and topics did not relate to Iranian culture.

4. The series contained too many testing exercises.

5. An adequate number of teacher's manuals was not provided.

6. Writing skill received too little attention; therefore, learners did not receive adequate practice in this skill.

Rezaee et al.'s (2013) study also evaluated the New Interchange textbook series. They attempted to compare and evaluate the series with a series entitled TopNotch, assessing each series' layout, skills, activities, language type, subject and content and practical considerations. The study sample included 42 Iranian EFL learners who had varying levels of proficiency in English. First, the subjects were divided into two groups. Then, each group was asked to evaluate one of the two series. An evaluative questionnaire was used to elicit the sample views. The study determined that most of the learners were unhappy with the TopNotch series. Many complained that the series' textbooks were too costly, out of date or difficult to access. By contrast, most students were satisfied with the New Interchange series and gave a majority of its features higher than average ratings.

Sahragard et al. (2009) carried out another evaluative study on the New Interchange series, with aims to explore the series, evaluate it and determine the extent that it applied to task- and communicative-based theories. The researchers consulted four ELT experts and used an evaluative checklist prepared by Littlejohn (1998). The study's results revealed that the New Interchange series focused on language usage and emphasised meaning rather than form. It is also likely that many of the respondents gave the majority of their attention to communicative competence. In other words, many believed that the textbook series unsuccessfully prepared its readers for the objectives that were outlined in the textbooks' prefaces.

In Litz's (2005) evaluation of the commercial textbook entitled English Firsthand 2, his aim was to determine the textbook's overall suitability and pedagogical value for the language program at Sung Kyun Kwan University in 2000 - 2001. He developed an evaluative checklist that investigated several of the textbook's features. These included layout and design, subject and content, a number of practical considerations(price, accessories, methodology, etc.), range and balance of activities, social and cultural considerations, skills integration and appropriateness and the language types that were represented in the textbook. The study sample included 8 teachers and 500 students who had been enrolled in the language program. The study's results found that the textbook's positive points far 
outweighed its negative ones. Each textbook appeared to be well organised and showed good integration of the four skills. In addition, its activities were diverse and encouraged communication during language learning. All supplementary materials were also provided or were made to be available. By contrast, some drawbacks of the textbook included repetitive activities, shortages of meaningful practice activities and a lack of a focus on ESP.

\section{Objective of the Study}

The current study aimed to evaluate the Cuttingedge textbook. It explored a number of the textbook's features that were related to language learning and instruction. These included skills, activities, language type, layout and design, subject and content and a select number of practical considerations (e.g., price and supplementary materials).

\section{Methodology}

\subsection{Participants}

Twelve EFL instructors, who currently teach the target textbook, contributed to the completion of this study. Each respondent was asked to express their opinions about the textbook in response to an evaluative questionnaire.

\subsection{Materials}

The textbook that was evaluated is currently being taught in the general English course (ENG 150) at Najran University's Preparatory Year Programme. The textbook is entitled Cuttingedge (2013) and was written by Sara Cunningham, Peter Moor and Jonathan Bygrave.

\subsection{Instruments}

The study used an evaluative questionnaire that was developed by Litz (2005). Permission was sought from the developer to use the questionnaire. The questionnaire consists of 40 items that have been divided into the following 6 categories: skills, activities, language type, layout and design, subject and content and practical considerations.

\subsection{Method of Data Analysis}

Instructors were asked to share their opinions about the textbook by using a questionnaire with a five-point scale (strongly agree, agree, undecided, disagree and strongly disagree). Frequencies, percentages, arithmetic means and standard deviations were calculated to determine the subjects' overall attitudes about the textbook and the degrees in which they agreed or disagreed with the evaluative statements that were represented in the questionnaire. The statistical package for social sciences (SPSS) was used for data analysis.

\section{Findings and Discussion}

This evaluation is based on the views that EFL instructors held in response to various aspects of the textbook. The categories that were evaluated included skills, activities, language type, layout and design, subject and content and practical considerations. In this section, we will discuss each of these features individually. 


\section{MlMacrothink}

\subsection{Practical Considerations}

Table 1. Practical Considerations

\begin{tabular}{|c|c|c|c|c|}
\hline & Item & Response & Percentage & Mean \\
\hline 1 & The price of the textbook is reasonable. & $\begin{array}{l}\text { strongly agree } \\
\text { agree } \\
\text { undecided } \\
\text { disagree } \\
\text { strongly disagree }\end{array}$ & \begin{tabular}{|l|}
0 \\
33.3 \\
33.3 \\
8.3 \\
25 \\
\end{tabular} & 2.75 \\
\hline 2 & The textbook is easily accessible. & $\begin{array}{l}\text { strongly agree } \\
\text { agree } \\
\text { undecided } \\
\text { disagree } \\
\text { strongly disagree }\end{array}$ & $\begin{array}{l}0 \\
33.3 \\
25 \\
25 \\
16.7 \\
\end{array}$ & 2.25 \\
\hline 3 & The textbook is a recent publication. & $\begin{array}{l}\text { strongly agree } \\
\text { agree } \\
\text { undecided } \\
\text { disagree } \\
\text { strongly disagree }\end{array}$ & $\begin{array}{l}16.7 \\
66.7 \\
16.7 \\
0 \\
0\end{array}$ & 4 \\
\hline 4 & $\begin{array}{l}\text { A teacher's guide, workbook, and audiotapes } \\
\text { accompany the textbook. }\end{array}$ & $\begin{array}{l}\text { strongly agree } \\
\text { agree } \\
\text { undecided } \\
\text { disagree } \\
\text { strongly disagree }\end{array}$ & $\begin{array}{l}8.3 \\
83.3 \\
0 \\
8.3 \\
0\end{array}$ & 3.92 \\
\hline 5 & $\begin{array}{l}\text { Author's views on language and methodology are } \\
\text { comparable to mine (Note: refer to the 'blurb' on } \\
\text { the back of the textbook). }\end{array}$ & $\begin{array}{l}\text { strongly agree } \\
\text { agree } \\
\text { undecided } \\
\text { disagree } \\
\text { strongly disagree }\end{array}$ & $\begin{array}{l}0 \\
91.7 \\
8.3 \\
0 \\
0\end{array}$ & 3.92 \\
\hline
\end{tabular}

Items $1-5$ represent the study's evaluation of practical considerations. According to Table 1, while $33.3 \%$ of the subjects agreed that the price of the textbook was reasonable, a similar number of subjects found the price of the textbook to be too high. Furthermore, although most of the instructors found the textbook to be inaccessible, $33.3 \%$ found it to be clear and easy to understand. $83.4 \%$ of the instructors believed that the textbook was a recent publication. Supplementary materials, such as workbooks, teachers' guides and audio CDs and/or tapes were reported to be readily available. A high percentage of instructors $(91.7 \%)$ claimed that the author's views on language and methodology were comparable to their own.

The average mean score of the textbook's practical considerations was3.37 (Table 3). According to the table below, judgments concerning agreements or disagreements in response to the evaluative statements depend on the average of each category's mean score. Therefore, it can be concluded that the instructors' views on practical considerations were unclear. 
Table 2. Interpretation of Average Mean Scores

\begin{tabular}{|l|l|}
\hline Mean Score Value Averages & Interpretation \\
\hline Between 1.00 and 1.80 & strongly disagree \\
Between 1.81 and 2.60 & disagree \\
Between 2.61 and 3.40 & undecided \\
Between 3.41 and 4.20 & agree \\
Between 4.21 and 5.00 & strongly agree \\
\hline
\end{tabular}

Table 3. The Average Mean Score of Each Category in the Questionnaire

\begin{tabular}{|l|l|l|}
\hline Evaluative Categories & Mean & Views \\
\hline Practical considerations & 3.37 & undecided \\
\hline Layout and design & 3.74 & agree \\
\hline Activities & 3.55 & agree \\
\hline Skills & 3.63 & agree \\
\hline Language type & 3.51 & agree \\
\hline Subject and content & 3.65 & agree \\
\hline Conclusion & 3.24 & undecided \\
\hline
\end{tabular}

\subsection{Layout and Design}

Table 4. Layout and Design

\begin{tabular}{|c|c|c|c|c|}
\hline & Item & Response & Percentage & Mean \\
\hline 6 & $\begin{array}{l}\text { The textbook includes a detailed overview of the } \\
\text { functions, structures and vocabulary that will be } \\
\text { taught in each unit. }\end{array}$ & $\begin{array}{l}\text { strongly agree } \\
\text { agree } \\
\text { undecided } \\
\text { disagree } \\
\text { strongly disagree }\end{array}$ & $\begin{array}{l}8.3 \\
58.3 \\
8.3 \\
25 \\
0\end{array}$ & 3.5 \\
\hline 7 & The layout and design is appropriate and clear. & $\begin{array}{l}\text { strongly agree } \\
\text { agree } \\
\text { undecided } \\
\text { disagree } \\
\text { strongly disagree }\end{array}$ & $\begin{array}{l}16.7 \\
50 \\
8.3 \\
25 \\
0\end{array}$ & 3.58 \\
\hline 8 & The textbook is organised effectively. & $\begin{array}{l}\text { strongly agree } \\
\text { agree } \\
\text { undecided } \\
\text { disagree } \\
\text { strongly disagree }\end{array}$ & $\begin{array}{l}16.7 \\
25 \\
41.7 \\
16.7 \\
0\end{array}$ & 3.42 \\
\hline 9 & $\begin{array}{l}\text { An adequate vocabulary list or glossary is } \\
\text { included. }\end{array}$ & $\begin{array}{l}\text { strongly agree } \\
\text { agree } \\
\text { undecided }\end{array}$ & $\begin{array}{l}16.7 \\
58.3 \\
16.7 \\
\end{array}$ & 3.83 \\
\hline
\end{tabular}




\begin{tabular}{|c|c|c|c|c|}
\hline & & $\begin{array}{l}\text { disagree } \\
\text { strongly disagree }\end{array}$ & $\begin{array}{l}8.3 \\
0\end{array}$ & \\
\hline 10 & $\begin{array}{l}\text { Adequate review sections and exercises are } \\
\text { included. }\end{array}$ & $\begin{array}{l}\text { strongly agree } \\
\text { agree } \\
\text { undecided } \\
\text { disagree } \\
\text { strongly disagree }\end{array}$ & $\begin{array}{l}25 \\
58.3 \\
8.3 \\
8.3 \\
0\end{array}$ & 4 \\
\hline 11 & $\begin{array}{l}\text { An adequate set of evaluation quizzes or testing } \\
\text { suggestions is included. }\end{array}$ & $\begin{array}{l}\text { strongly agree } \\
\text { agree } \\
\text { undecided } \\
\text { disagree } \\
\text { strongly disagree }\end{array}$ & $\begin{array}{l}8.3 \\
66.7 \\
16.7 \\
8.3 \\
0\end{array}$ & 3.75 \\
\hline 12 & $\begin{array}{l}\text { The teacher's book contains guidance about how } \\
\text { the textbook can be used to the utmost advantage. }\end{array}$ & $\begin{array}{l}\text { strongly agree } \\
\text { agree } \\
\text { undecided } \\
\text { disagree } \\
\text { strongly disagree }\end{array}$ & $\begin{array}{l}33.3 \\
50 \\
16.7 \\
0 \\
0\end{array}$ & 4.17 \\
\hline
\end{tabular}

Items $6-12$ evaluate the textbook's layout and design. About $67 \%$ of the respondents agreed, and $25 \%$ of the respondents disagreed, with the statement that claimed that the textbook contained a detailed overview of the functions, structures and vocabulary that would be taught in each unit. Additionally, $68 \%$ of the respondents thought that the textbook's layout and design was both clear and appropriate. Roughly $42 \%$ of the respondents found the textbook's organisation to be effective, and $16.7 \%$ of the respondents considered the textbook's organisation to be ineffective. According to table 4 about $3 / 4$ of the sample, a vocabulary list (glossary) was included within the textbook. While around $83 \%$ of the respondents agreed that the review sections and exercises that were included in the textbook were sufficient, $8.3 \%$ of the respondents found the review sections and exercises to be insufficient. Similarly, most respondents agreed that an adequate set of evaluative quizzes and/or testing suggestions were included. Most instructors (83.3\%) also agreed that the teacher's book contained guidance about how the textbook could be used to its highest potential.

Table 3 indicates that the overall evaluation of layout and design was positive with an average mean score of 3.74 , indicating that the subjects were mostly satisfied with the textbook's layout and design.

\subsection{Activities}

Table 5. Activities

\begin{tabular}{|l|l|l|l|l|}
\hline & Item & Response & Percentage & Mean \\
\hline 14 & The textbook provides a balance of activities (Ex. & strongly agree & 8.3 & 3.5 \\
\hline
\end{tabular}




\begin{tabular}{|c|c|c|c|c|}
\hline & $\begin{array}{l}\text { There is an even distribution of free vs. controlled } \\
\text { exercises and tasks that focus on both fluent and } \\
\text { accurate production). }\end{array}$ & $\begin{array}{l}\text { agree } \\
\text { undecided } \\
\text { disagree } \\
\text { strongly disagree }\end{array}$ & $\begin{array}{l}50 \\
25 \\
16.7 \\
0\end{array}$ & \\
\hline 15 & $\begin{array}{l}\text { The activities encourage sufficient communicative } \\
\text { and meaningful practice. }\end{array}$ & $\begin{array}{l}\text { strongly agree } \\
\text { agree } \\
\text { undecided } \\
\text { disagree } \\
\text { strongly disagree }\end{array}$ & $\begin{array}{l}16.7 \\
58.3 \\
8.3 \\
16.7 \\
0\end{array}$ & 3.75 \\
\hline 16 & $\begin{array}{l}\text { The activities incorporate individual, pair and } \\
\text { group work. }\end{array}$ & $\begin{array}{l}\text { strongly agree } \\
\text { agree } \\
\text { undecided } \\
\text { disagree } \\
\text { strongly disagree }\end{array}$ & $\begin{array}{l}8.3 \\
66.7 \\
8.3 \\
16.7 \\
0\end{array}$ & 3.67 \\
\hline 17 & $\begin{array}{l}\text { The grammar points and vocabulary items are } \\
\text { introduced in motivating and realistic contexts. }\end{array}$ & $\begin{array}{l}\text { strongly agree } \\
\text { agree } \\
\text { undecided } \\
\text { disagree } \\
\text { strongly disagree }\end{array}$ & $\begin{array}{l}8.3 \\
33.3 \\
33.3 \\
25 \\
0\end{array}$ & 3.25 \\
\hline 18 & $\begin{array}{l}\text { The activities promote creative, original and } \\
\text { independent responses. }\end{array}$ & $\begin{array}{l}\text { strongly agree } \\
\text { agree } \\
\text { undecided } \\
\text { disagree } \\
\text { strongly disagree }\end{array}$ & $\begin{array}{l}8.3 \\
50 \\
25 \\
16.7 \\
0\end{array}$ & 3.5 \\
\hline 19 & $\begin{array}{l}\text { The tasks are conducive to the internalisation of } \\
\text { newly introduced language. }\end{array}$ & $\begin{array}{l}\text { strongly agree } \\
\text { agree } \\
\text { undecided } \\
\text { disagree } \\
\text { strongly disagree }\end{array}$ & $\begin{array}{l}8.3 \\
58.3 \\
16.7 \\
16.7 \\
0\end{array}$ & 3.58 \\
\hline 20 & $\begin{array}{l}\text { The textbook's activities can be modified or } \\
\text { supplemented easily. }\end{array}$ & $\begin{array}{l}\text { strongly agree } \\
\text { agree } \\
\text { undecided } \\
\text { disagree } \\
\text { strongly disagree }\end{array}$ & $\begin{array}{l}8.3 \\
58.3 \\
16.7 \\
16.7 \\
0\end{array}$ & 3.58 \\
\hline
\end{tabular}

Items $14-20$ evaluate the textbook's activities. While Table 5 shows that more than half of the subjects believed that the book's activities were various and balanced, roughly $17 \%$ of the respondents disagreed with this assessment. According to Table 5, 75\% of the study's subjects, the textbook's use of communicative and meaningful practice activities was sufficient. This same percentage of respondents agreed that the textbook's activities incorporated both paired and group work. Although about $40 \%$ of the instructors thought that the textbook's grammar 
points and vocabulary items were introduced in motivating and realistic contexts, $25 \%$ of the respondents disagreed with this assessment. More than $65 \%$ of the instructors agreed that the textbook's activities could be modified or supplemented easily. According to Table 3, the average mean score for the category of activities was 3.55. This means that most of the subjects agreed with the statements that were addressed in this section of the questionnaire.

\subsection{Skills}

Table 6. Skills

\begin{tabular}{|c|c|c|c|c|}
\hline & Item & Response & Percentage & Mean \\
\hline 21 & $\begin{array}{l}\text { The materials include and focus on the skills that } \\
\text { I/my students need to practice. }\end{array}$ & $\begin{array}{l}\text { strongly agree } \\
\text { agree } \\
\text { undecided } \\
\text { disagree } \\
\text { strongly disagree }\end{array}$ & \begin{tabular}{l|l|}
8.3 \\
66.7 \\
8.3 \\
16.7 \\
0
\end{tabular} & 3.67 \\
\hline 22 & $\begin{array}{l}\text { The materials provide an appropriate balance of the } \\
\text { four language skills. }\end{array}$ & $\begin{array}{l}\text { strongly agree } \\
\text { agree } \\
\text { undecided } \\
\text { disagree } \\
\text { strongly disagree }\end{array}$ & $\begin{array}{l}8.3 \\
58.3 \\
16.7 \\
16.7 \\
0\end{array}$ & 3.58 \\
\hline 23 & $\begin{array}{l}\text { The textbook pays attention to sub-skills - i.e. } \\
\text { listening for gist, note-taking, skimming for } \\
\text { information, etc. }\end{array}$ & $\begin{array}{l}\text { strongly agree } \\
\text { agree } \\
\text { undecided } \\
\text { disagree } \\
\text { strongly disagree }\end{array}$ & $\begin{array}{l}8.3 \\
50 \\
16.7 \\
25 \\
0 \\
\end{array}$ & 3.42 \\
\hline 24 & $\begin{array}{l}\text { The textbook highlights and practices natural } \\
\text { pronunciation (e.g., stress and intonation). }\end{array}$ & $\begin{array}{l}\text { strongly agree } \\
\text { agree } \\
\text { undecided } \\
\text { disagree } \\
\text { strongly disagree }\end{array}$ & $\begin{array}{l}8.3 \\
66.7 \\
16.7 \\
8.3 \\
0\end{array}$ & 3.75 \\
\hline 25 & $\begin{array}{l}\text { The practice of individual skills is integrated into } \\
\text { the practice of other skills. }\end{array}$ & $\begin{array}{l}\text { strongly agree } \\
\text { agree } \\
\text { undecided } \\
\text { disagree } \\
\text { strongly disagree }\end{array}$ & \begin{tabular}{l|}
8.3 \\
66.7 \\
16.7 \\
8.3 \\
0
\end{tabular} & 3.75 \\
\hline
\end{tabular}

Items $21-25$ evaluate the textbook's language skills. 75\% of the instructors agreed that the textbook focused on skills that their students needed. The same percentage of respondents agreed that there was a good balance of the four language skills. Respondents also agreed that individual skills had been integrated into the practice of other skills. According to Table 6, more than half of the study's subjects, sub skills, such as note taking, skimming for information and listening for the gist of a conversation, were emphasised. While $75 \%$ of the respondents agreed that the textbook emphasised practices that encouraged natural 


\section{I Macrothink}

pronunciation, $8.3 \%$ of the respondents disagreed with this assessment. In general, the textbook's skills component rated highly with an overall mean score of 3.63.

\subsection{Language Type}

Table 7. Language Type

\begin{tabular}{|c|c|c|c|c|}
\hline & Item & Response & Percentage & Mean \\
\hline 26 & $\begin{array}{l}\text { The language used in the textbook is authentic ( i.e. } \\
\text { like real-life English). }\end{array}$ & $\begin{array}{l}\text { strongly agree } \\
\text { agree } \\
\text { undecided } \\
\text { disagree } \\
\text { strongly disagree }\end{array}$ & $\begin{array}{l}8.3 \\
66.7 \\
8.3 \\
16.7 \\
0\end{array}$ & 3.67 \\
\hline 27 & $\begin{array}{l}\text { The language used is at the right level for } \\
\text { my(students') current English ability. }\end{array}$ & $\begin{array}{l}\text { strongly agree } \\
\text { agree } \\
\text { undecided } \\
\text { disagree } \\
\text { strongly disagree }\end{array}$ & $\begin{array}{l}8.3 \\
41.7 \\
25 \\
25 \\
0\end{array}$ & 3.33 \\
\hline 28 & $\begin{array}{l}\text { The progression of grammar points and vocabulary } \\
\text { items is appropriate. }\end{array}$ & $\begin{array}{l}\text { strongly agree } \\
\text { agree } \\
\text { undecided } \\
\text { disagree } \\
\text { strongly disagree }\end{array}$ & $\begin{array}{l}8.3 \\
50 \\
25 \\
16.7 \\
0 \\
\end{array}$ & 3.5 \\
\hline 29 & $\begin{array}{l}\text { The grammar points are presented with easy and } \\
\text { brief examples and explanations. }\end{array}$ & $\begin{array}{l}\text { strongly agree } \\
\text { agree } \\
\text { undecided } \\
\text { disagree } \\
\text { strongly disagree }\end{array}$ & \begin{tabular}{l|}
8.3 \\
41.7 \\
33.3 \\
16.7 \\
0
\end{tabular} & 3.42 \\
\hline 30 & $\begin{array}{l}\text { The language functions exemplify English that } \mathrm{I} / \mathrm{my} \\
\text { students will be likely to use. }\end{array}$ & $\begin{array}{l}\text { strongly agree } \\
\text { agree } \\
\text { undecided } \\
\text { disagree } \\
\text { strongly disagree }\end{array}$ & $\begin{array}{l}8.3 \\
58.3 \\
16.7 \\
16.7 \\
0 \\
\end{array}$ & 3.58 \\
\hline 31 & $\begin{array}{l}\text { The language represents a diverse range of registers } \\
\text { and accents. }\end{array}$ & $\begin{array}{l}\text { strongly agree } \\
\text { agree } \\
\text { undecided } \\
\text { disagree } \\
\text { strongly disagree }\end{array}$ & \begin{tabular}{l|}
8.3 \\
50 \\
33.3 \\
8.3 \\
0 \\
\end{tabular} & 3.58 \\
\hline
\end{tabular}

Items $26-31$ evaluate the textbook's language type. This feature was explored through assessments of authenticity, the diversity of accents and registers, the progression of vocabulary and grammar points and the suitability of the textbook in relation to students' proficiency with the language. While $75 \%$ of the instructors agreed that the language that was 
used in the textbook was authentic, $16.7 \%$ of the instructors disagreed with this assessment. About $50 \%$ of the respondents agreed, and at least $25 \%$ of the respondents disagreed, with the statement that claimed that the textbook was suited to their students' levels of English. Roughly $60 \%$ of the instructors thought that the textbook's progression of grammar points and vocabulary items was appropriate. About half of the respondents believed that the textbook offered easy and brief examples and explanations of grammar points. In response to language functions, more than $65 \%$ of the subjects agreed that the textbook taught English that students would be likely to use in the future. Finally, about $60 \%$ of the instructors thought that a diverse selection of accents and registers were represented in the textbook. According to Table 3, the overall mean score of the language type in the target textbook is 3.51. This means that most of the instructors were satisfied with the textbook's representation of this feature.

\subsection{Subject and Content}

Table 8. Subject and Content

\begin{tabular}{|c|c|c|c|c|}
\hline & Item & Response & Percentage & Mean \\
\hline 32 & $\begin{array}{l}\text { The subject and content of the textbook is relevant } \\
\text { to my(students') needs as an English language } \\
\text { learner(s). }\end{array}$ & $\begin{array}{l}\text { strongly agree } \\
\text { agree } \\
\text { undecided } \\
\text { disagree } \\
\text { strongly disagree }\end{array}$ & $\begin{array}{l}8.3 \\
50 \\
16.7 \\
25 \\
0 \\
\end{array}$ & 3.42 \\
\hline 33 & $\begin{array}{l}\text { The subject and content of the textbook is } \\
\text { generally realistic. }\end{array}$ & $\begin{array}{l}\text { strongly agree } \\
\text { agree } \\
\text { undecided } \\
\text { disagree } \\
\text { strongly disagree }\end{array}$ & $\begin{array}{l}8.3 \\
66.7 \\
16.7 \\
8.3 \\
0 \\
\end{array}$ & 3.75 \\
\hline 34 & $\begin{array}{l}\text { The subject and content of the textbook is } \\
\text { interesting, challenging and motivating. }\end{array}$ & $\begin{array}{l}\text { strongly agree } \\
\text { agree } \\
\text { undecided } \\
\text { disagree } \\
\text { strongly disagree }\end{array}$ & $\begin{array}{l}8.3 \\
66.7 \\
8.3 \\
16.7 \\
0 \\
\end{array}$ & 3.67 \\
\hline 35 & $\begin{array}{l}\text { There is sufficient variety in the subject and } \\
\text { content of the textbook. }\end{array}$ & $\begin{array}{l}\text { strongly agree } \\
\text { agree } \\
\text { undecided } \\
\text { disagree } \\
\text { strongly disagree }\end{array}$ & $\begin{array}{l}16.7 \\
50 \\
16.7 \\
16.7 \\
0 \\
\end{array}$ & 3.67 \\
\hline 36 & $\begin{array}{l}\text { The materials are not culturally biased and they do } \\
\text { not portray any negative stereotypes. }\end{array}$ & $\begin{array}{l}\text { strongly agree } \\
\text { agree } \\
\text { undecided } \\
\text { disagree } \\
\text { strongly disagree }\end{array}$ & $\begin{array}{l}8.3 \\
66.7 \\
16.7 \\
8.3 \\
0\end{array}$ & 3.75 \\
\hline
\end{tabular}




\section{Macrothink}

Items $32-36$ evaluate the textbook's subject and content. During assessments of a textbook's learning material, it is essential to investigate that material's subject and content, or more specifically, its variety, realism, cultural biases, ability to motivate, interesting features and relevance to learners' needs. Table 8 shows that $66.7 \%$ of the study sample agreed that the subject and content of the textbook was realistic, motivating, challenging and interesting. Furthermore, many agreed that the textbook contained no cultural bias or negative stereotypes. More than half of the respondents believed that the textbook's subject and content were linked to their learners' specific needs. Many also agreed that the textbook's subject and content displayed sufficient variety. According to Table 3, the overall mean score of the textbook's subject and content is 3.65. This means that most of the instructors were satisfied with the textbook's representation of this feature.

\subsection{Conclusion}

Table 9. Conclusion

\begin{tabular}{|c|c|c|c|c|}
\hline & Item & Response & Percentage & Mean \\
\hline 37 & $\begin{array}{l}\text { The textbook is appropriate for the } \\
\text { language-learning aims of my institution. }\end{array}$ & $\begin{array}{l}\text { strongly agree } \\
\text { agree } \\
\text { undecided } \\
\text { disagree } \\
\text { strongly disagree }\end{array}$ & $\begin{array}{l}8.3 \\
41.7 \\
25 \\
25 \\
0\end{array}$ & 3.33 \\
\hline 38 & $\begin{array}{l}\text { The textbook is suitable for co-ed, small, medium } \\
\text { and homogeneous university classes. }\end{array}$ & $\begin{array}{l}\text { strongly agree } \\
\text { agree } \\
\text { undecided } \\
\text { disagree } \\
\text { strongly disagree }\end{array}$ & $\begin{array}{l}8.3 \\
33.3 \\
41.7 \\
16.7 \\
0\end{array}$ & 3.33 \\
\hline 39 & $\begin{array}{l}\text { The textbook raises my(students') interest in further } \\
\text { English language study. }\end{array}$ & $\begin{array}{l}\text { strongly agree } \\
\text { agree } \\
\text { undecided } \\
\text { disagree } \\
\text { strongly disagree }\end{array}$ & $\begin{array}{l}8.3 \\
25 \\
50 \\
16.7 \\
0\end{array}$ & 3.25 \\
\hline 40 & I would choose to teach this textbook again. & $\begin{array}{l}\text { strongly agree } \\
\text { agree } \\
\text { undecided } \\
\text { disagree } \\
\text { strongly disagree }\end{array}$ & $\begin{array}{l}8.3 \\
25 \\
33.3 \\
33.3 \\
0\end{array}$ & 3.08 \\
\hline
\end{tabular}

Items in this final section of the questionnaire draw on conclusive questions related to the textbook's suitability for the language program at Najran University's Preparatory Year Programme. According to Table 9, about 50\% of the instructors agreed that the textbook appropriately met the aims of their institution's language program, while $25 \%$ of the instructors disagreed with this assessment. Although roughly $33 \%$ of the respondents thought 
that the textbook raised their students' interest in studying the English language in the future, $16.7 \%$ of the respondents disagreed with this assessment, and $50 \%$ of the respondents were undecided. When asked if they would choose to teach the target textbook in the future, the subjects' responses were largely unclear. About $33 \%$ of the respondents agreed and disagreed with this statement, respectively. Because the overall mean score of this section of the questionnaire was 3.24, it is unclear as to whether the instructors' responses to these items were completely positive or negative.

\section{Conclusion}

The target textbook's evaluation criteria were divided into the following primary categories: skills, activities, language type, layout and design, subject and content and practical considerations. Table 3 summarises the mean scores of each of these categories. It is clear that the respondents were most satisfied with the textbook's layout and design (mean score=3.74), followed by its subject and content (3.65), its skills component (3.63), its activities (3.55) and its language type (3.51). Respondents' views on the textbook's practical considerations were unclear. Most responses for this item were placed under the 'undecided' category.

Because most of the instructors were pleased with a majority of the items that were evaluated, the textbook will likely prove to be suitable for the future instruction of English at Najran University's Preparatory Year Programme. However, it is important to note that this evaluation was based on the views of a select sample of instructors. It is therefore highly recommend that learners be given the opportunity to evaluate the textbook, as well.

\section{References}

Byrd, P. (2001). Textbooks: Evaluation for selection and analysis for implementation. In M. Celce-Murcia (Ed.) ( $3^{\text {rd }}$ ed.), Teaching English as a second or foreign language. Boston, Mass.: Heinle and Heinle.

Cunningsworth, A. (1995). Choosing your coursebook. Oxford: Heinmann.

Ellis, R. (1997). The empirical evaluation of language teaching materials. English Language Teaching Journal, 51 (1), 36 - 42. http://dx.doi.org/10.1093/elt/51.1.36

Ellis, R. (1998). The evaluation of communicative tasks. In B. Tomlinson (Ed.), Materials development in language teaching. Cambridge: Cambridge University Press.

Grant, N. (1987). Making the most of your textbook. London: Longman.

Hill, D. A. (1997). Review of 'Choosing your coursebook'. English Language Teaching Journal, 51(1),83-85.

Littlejohn, A. (1998). The analysis of language teaching materials: Inside the Trojan horse.In B. Tomlinson (Ed.), Materials development in language teaching. Cambridge: Cambridge University Press.

Litz, D. (2005) Textbook evaluation and management: A South Korean case study. Asian EFL 
Journal. Retrieved from http://www.asian-efl-journal.com/Litz_thesis.pdf

McGrath, I. (2002). Materials evaluation and design for language teaching. Edinburgh: Edinburgh University Press.

Rezaee, A., Kouhpaeenejad, M., \& Mohammadi, A. (2013). Iranian EFL learners' perspective on New Interchange series and Top-Notch series: A comparative study. Social and Behavioral Sciences, (70), 827-840. http://dx.doi.org/10.1016/j.sbspro.2013.01.128

Riasati, M., \& Zare, P. (2010). Textbook evaluation: EFL teachers' perspective on New Interchange. Studies in Literature and Language, 1(1),54-60.

Rubdy, R. (2003). Selection of materials. In B. Tomlinson (Ed.), Developing materials for language teaching. London: Continuum.

Sahragard, R., Rahimi, A., \& Zaremoayeddi, I. (2009). An in-depth evaluation of Interchange series. Porta Linguarum, 3(12),37-54.

Tomlinson, B. (Ed.). (1998). Materials development in language teaching. Cambridge: Cambridge University Press.

\section{Copyright Disclaimer}

Copyright for this article is retained by the author(s), with first publication rights granted to the journal.

This is an open-access article distributed under the terms and conditions of the Creative Commons Attribution license (http://creativecommons.org/licenses/by/3.0/). 